\title{
Effects of Captopril on the Distribution of Left Ventricular Output with Ventricular Septal Defect
}

\author{
MARK M. BOUCEK AND RICHARD L. CHANG \\ Department of Pediatrics, Division of Cardiology, University of Utah School of Medicine and Primary Children's \\ Medical Center, Salt Lake City, Utah 84132
}

\begin{abstract}
The renin-angiotensin system is activated by congestive heart failure associated with a ventricular septal defect (VSD). To determine the effect of angiotensinconverting enzyme inhibition on the hemodynamics with VSD, the dose response curve of captopril was measured in lambs. Furthermore, the effect of captopril on the distribution of systemic output was determined by the radionuclide-labeled microsphere technique. A total of 12 lambs (less than 1 month old) with VSD were instrumented and a minimum of five animals was tested for each data point. Captopril $(0.05-10 \mathrm{mg} / \mathrm{kg})$ caused dose-dependent vascular changes. At a dose of $2 \mathrm{mg} / \mathrm{kg}$, maximal hemodynamic effects were observed. The systemic resistance fell by 28 $\pm 9 \%$ (mean $\pm \mathrm{SD}, p<0.05, n=9$ ), whereas pulmonary arteriolar resistance rose by $113 \pm 34 \%(p<0.05)$. These vascular changes caused a reduction in the ratio of pulmonary to systemic flow from $3.31 \pm 0.59$ to $2.19 \pm 0.29$ $(-34 \%, p<0.05)$ and a reduction in left-to-right shunt volume by $30 \%(p<0.05)$. The left atrial pressure fell from $17.3 \pm 3.4$ to $10.8 \pm 2.8 \mathrm{~mm} \mathrm{Hg}(-38 \%, p<0.05)$. Mean aortic pressure was unchanged $(71.2 \pm 8.1$ versus $67.4 \pm 9.1$ ). Forward flow from the left ventricle increased from $2.17 \pm 0.46$ to $2.86 \pm 0.54 \mathrm{liter} / \mathrm{min} / \mathrm{M}^{2}(p<0.05)$. Microsphere-determined organ blood flow to the heart, kidney, liver, duodenum, and skeletal muscle was preserved after a $5 \mathrm{mg} / \mathrm{kg}$ dose of captopril and, in fact, tended to increase, but the changes were not significant. The myocardial endocardial to epicardial flow ratio increased from $1.17 \pm 0.27$ to $1.49 \pm 0.14(+27 \%, p<0.05)$. The data indicate that captopril caused dose-dependent changes in the distribution of left ventricular output in lambs with VSD, reducing total pulmonary flow while preserving organ blood flow. (Pediatr Res 24: 499-503, 1988)
\end{abstract}

\section{Abbreviations}

VSD, ventricular septal defect

ANF, atrial natriuretic factor

There is clinical and experimental evidence that the reninangiotensin system is stimulated both by alterations in myocardial performance and by structural lesions that result in a leftto-right intracardiac shunt (1-4). Presumably, the stimulus for renin release is a perceived reduction in renal perfusion and, as

Received February 1, 1988; accepted June 16, 1988.

Correspondence and reprint requests Mark M. Boucek, M.D., Director of Pediatric Cardiology, Loma Linda University, School of Medicine, Loma Linda California 92350.

Supported in part by the Utah Heart Association and USPHS HL 2780203. such, serves an homeostatic role to preserve renal function (5). However, this renal-renin response may further impair cardiac performance by increasing afterload (1). The increased afterload may also aggravate the pathophysiology of structural defects with a left-to-right shunt (6).

However, local autoregulation may maintain blood flow to vital organs, offsetting the generalized vasoconstriction due to angiotensin II. The role of the increased angiotensin II production may then be to maintain arterial pressure in the autoregulatory range and to preserve organ blood flow despite a reduction in cardiac output (5). If that were the case, inhibiting the formation of angiotensin II with a converting enzyme inhibitor might actually impair renal function and possibly organ blood flow in general if the arterial pressure fell below the autoregulatory range. To test the hypothesis that the stimulation in the renin-angiotensin system with a structural heart defect is pathologic and adversely affects the hemodynamics, we created a VSD in lambs. We then determined the dose reponse characteristics of captopril, an angiotensin-converting enzyme inhibitor. Both the global hemodynamics and the regional organ blood flow effects of captopril were studied in nonanesthetized, chronically instrumented animals with electromagnetic flow probes and radionuclide-labeled microsphere injections.

\section{MATERIALS AND METHODS}

The technique used to create the VSD has been previously described (4) and was not significantly altered. In essence, lambs were obtained in the first 2 wk of life and weaned to bottle feedings of a fixed amount. A plastic grommet $(8 \mathrm{~mm}$ ID) was subsequently inserted across the ventricular septum after entry via the right atrial appendage. All surgery was performed with ketamine anesthesia. After a 10-day recovery period, the lambs were instrumented as previously described (7) with aortic and pulmonary artery catheters and electromagnetic flow probes, as well as left and right atrial pressure catheters. Animals were then allowed to recover for $1 \mathrm{wk}$ after instrumentation before any data collection.

On the day of study, the lambs were brought to the laboratory and allowed to equilibrate for $30 \mathrm{~min}$ before drug administration. An arterial blood gas analysis was performed. Control data were then obtained which included phasic and mean aortic and pulmonary artery pressures and flows and left and right atrial pressures. The heart rate was continuously monitored. We have previously shown that this model is stable over the 2-h period of observation (7). A total of 12 lambs had a VSD made, and a minimum of five animals was used for each experimental evaluation.

Drug administration. Captopril was supplied by E. R. Squibb and Sons, Inc., Princeton, NJ. The drug was stored under vacuum at $4^{\circ} \mathrm{C}$, and thin-layer chromatography showed no change 
in purity during storage. The captopril was prepared fresh on the day of experimentation and was administered intravenously as a bolus in doses of $0.05,0.5,2.0,5.0$, and $10.0 \mathrm{mg} / \mathrm{kg}$. At doses of $2 \mathrm{mg} / \mathrm{kg}$ or more, only one dose was given in a 24 -h period. The drug was filtered through a $0.45 \mu$ Millipore filter before administration to the animals to sterilize the solution. Hemodynamic variables were then monitored and recorded every $15 \mathrm{~min}$ for 2 $\mathrm{h}$ after drug administration.

Blood flow determinations. Electromagnetic flow probes were calibrated (in vitro) before implantation on lamb blood vessels of a similar size and thickness to those expected. On the day of data collection, the probe cable was attached to a Biotronix 613 sinie rvave flow meter, and only one probe was energized at any given time to prevent cross-talk between the different probes. The mean flow value was used to determine flow in either the ascending aorta or main pulmonary artery as previously described (7). Blood flow determinations were performed with each data point, and paired evaluations were performed before and immediately after the injection of microspheres.

Microsphere injections. To determine organ blood flow, radiolabeled microsphere injections were performed on six lambs using standard techniques (8,9). Approximately $2.0 \times 10^{6} 15 \mu$ microspheres labeled with either $85-\mathrm{Sr}, 51-\mathrm{Cr}$, or $141-\mathrm{Ce}$ were counted, agitated, and then injected over $20 \mathrm{~s}$ via the left atrial catheter. The heart rate and blood pressure were monitored during the injection and were noted to be stable. A reference blood flow sample was withdrawn at approximately $10 \mathrm{ml} / \mathrm{min}$ with a Harvard infusion pump from the thoracic-aortic arterial catheter for $1.5 \mathrm{~min}$. Arterial samples evaluated after this withdrawal phase had only background activity. Microsphere injections were performed in the control period and then again 45 min after a captopril dose of $5 \mathrm{mg} / \mathrm{kg}$. The order of microsphere label used for injections was varied randomly. Only two injections were performed in each animal. At the end of the data collection period, the lambs were euthanized. The heart, lungs, and kidneys were then dissected free of connective tissue and fat. The myocardium was divided into right ventricular, septal, and left ventricular components. In addition, a $1.5-\mathrm{cm}$ punch biopsy specimen was obtained from the left ventricular free wall, away from the papillary muscles, and this section was divided in half into endocardial and epicardial portions with a slicing device. The myocardial thickness was recorded. Both the right and left kidneys were harvested and counted and were compared as a control for the adequacy of microsphere mixing. Large biopsy specimens (approximately $25 \mathrm{~g}$ ) were obtained from the liver, duodenum, and the quadriceps. Samples were counted in a packard gamma spectrometer. Isotope separation was performed with a least squares analysis, and the data were expressed as the percent of total radioactivity injected per gram of tissue.

Data calculation and statistical analyses. All data were expressed as the mean and SD from number of animals. Systemic and pulmonary arteriolar resistance was calculated and hemodynamic data evaluated as previously described (7). The left ventricular external minute work was calculated as the product of total left ventricular output times mean aortic blood pressure because the VSD was pressure restrictive. The organ blood flow was derived from both the microsphere data and the electromagnetic flow data. The reason for using the combined evaluation is that with a VSD portion (if not most) of the microspheres may be removed from the systemic circulation (left ventricle) to the pulmonary circulation before adequate mixing, even with a left atrial injection. To accomodate this potential technical problem, we used the following equation to calculate the organ blood flow. Inasmuch as total systemic blood flow (minus coronary blood flow) from the ascending aortic flow probe was known and the percent of total injected microspheres that appeared in the percent of cardiac output in the aortic reference sample was known, the percent of injected microspheres which actually appeared in the systemic circulation could be calculated. Thus the following equations were generated:

$$
\text { organ flow } Q_{x}=\frac{Q_{s}\left(M_{x} / M_{T}\right)}{M_{Q_{s}} / M_{T}}
$$

which is reduced to $\mathrm{Q}_{\mathrm{x}}=\frac{\mathrm{Q}_{\mathrm{s}} \mathrm{M}_{\mathrm{x}}}{\mathrm{M}_{\mathrm{Qs}}}$

where $\mathrm{M}_{\mathrm{Qs}}=\frac{\mathrm{M}_{\mathrm{REF}}}{\left(\mathrm{Q}_{\mathrm{REF}} / \mathrm{Q}_{\mathrm{s}}\right)}$

$\left(Q_{\mathrm{x}}=\right.$ unknown organ blood flow, $\mathrm{Q}_{\mathrm{s}}=$ cardiac output (flow probe), $\mathrm{Q}_{\mathrm{REF}}=$ aortic reference sample withdrawal rate, $\mathrm{M}_{\mathrm{X}}=$ the number of microspheres in organ $\mathrm{x}, \mathrm{M}_{\mathrm{T}}=$ the total number of microspheres injected, $\mathrm{M}_{\mathrm{Q}_{5}}=$ the total number of microspheres in the systemic blood flow, and $\mathrm{M}_{\mathrm{REF}}=$ the total number of microspheres in the reference sample.)

The statistical evaluation of the data was performed with an analysis of variance and Dunnett's technique for comparing posttreatment values with a control. The effects of captopril on organ blood flow were evaluated with a paired $t$ test and the Bonferroni adjustment of the critical values. A value of $p<0.05$ was chosen to indicate a significant effect.

\section{RESULTS}

Hemodynamics. There was a dose-dependent reduction in systemic resistance $30 \mathrm{~min}$ after the intravenous administration of captopril. The peak reduction of $36 \%$ occurred a a dose of 5 $\mathrm{mg} / \mathrm{kg}$. The $\mathrm{ED}_{50}$ for the reduction in systemic resistance was approximately $0.5 \mathrm{mg} / \mathrm{kg}$. The reduction in systemic resistance after captopril reached peak effect by $30 \mathrm{~min}$ and plateaued during the remainder of the observation period. The pulmonary arteriolar resistance showed a dose-dependent increase after captopril with a maximum increase at $30 \mathrm{~min}$ of $75 \%$ at a dose of 2 $\mathrm{mg} / \mathrm{kg}$ (Fig. 1); by $60 \mathrm{~min}$ this had increased to $113 \%$ (Fig. 2). At a dose of $2 \mathrm{mg} / \mathrm{kg}$ or more, the effects of captopril on the vascular beds persisted for over $2 \mathrm{~h}$ but had disappeared by 24 h. The systemic output was increased after captopril with a similar dose response as seen for the systemic resistance. After a $2 \mathrm{mg} / \mathrm{kg}$ dose of captopril, the $\mathrm{Q}_{\mathrm{p}} / \mathrm{Q}_{\mathrm{s}}$ ratio decreased from 3.31 \pm 0.59 to $2.19 \pm 0.29$, the left-to-right shunt fell by $30 \%$, and the systemic flow increased from $2.17 \pm 0.46$ to $2.86 \pm 0.54$ liter $/ \mathrm{min} / \mathrm{M}^{2}(+31 \%, p<0.05)$.

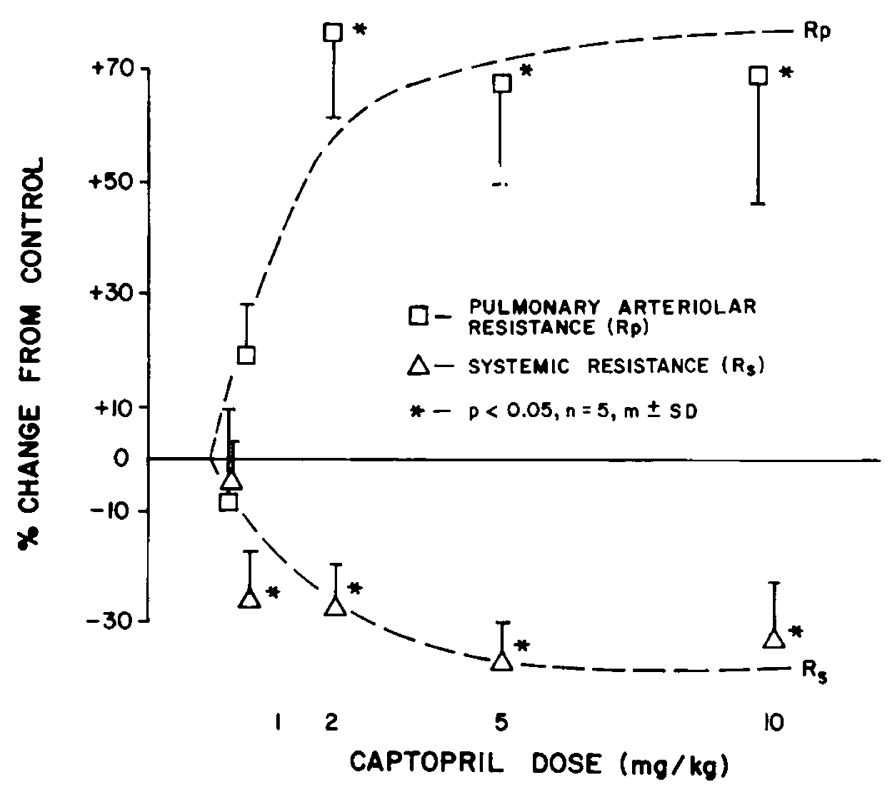

Fig. 1. Dose response curve of the systemic $\left(R_{s}\right)$ and pulmonary arteriolar resistance $\left(R_{p}\right)$ to captopril in lambs with VSD. 
At $30 \mathrm{~min}$, after a dose of $5 \mathrm{mg} / \mathrm{kg}$, the systemic output increased by $33 \%$, and the total pulmonary blood flow (systemic venous return and left-to-right ventricular level shunt) decreased by $17 \%$. However, the left-to-right shunt flow across the VSD was reduced by $37 \%$ (Table 1). Therefore, the fraction of left ventricular output distributed to the systemic circulation increased from 31 to $48 \%$. The $33 \%$ increase in total systemic output was accompanied by a $30 \%$ decrease in indexed left ventricular external minute work (Table 1). These hemodynamic changes were significant.

Despite only a $17 \%$ reduction in total left ventricular output (total pulmonary blood flow), the mean left atrial pressure fell by $25 \%$ at 30 min and continued to decrease with a maximum of $38 \%$ at $1 \mathrm{~h}$. The left ventricular external minute work, when normalized to the mean left atrial pressure, was unchanged ( 30 versus $28 \mathrm{liter} / \mathrm{min} / \mathrm{M}^{2}$ ). The heart rate was not significantly changed by any dose of captopril at any point in time. The mean aortic pressure (Table 2) decreased from $71.2 \pm 8.1$ to $67.4 \pm$ $9.1 \mathrm{~mm} \mathrm{Hg}$ after the $2 \mathrm{mg} / \mathrm{kg}$ dose of captopril, but this was an insignificant change. There was no significant change in either the aortic or pulmonary pressures at any observation point or dose.

Microsphere data. The hemodynamic characteristics of the six lambs studied with microspheres were similar to the other animals studied for the dose response to captopril. The arterial blood gas analysis was normal before microsphere injection, and there was no significant change in any of the arterial blood gas parameters after microsphere infusion. Similarly, no significant change in heart rate or blood pressure was detected during the infusions. Paired evaluations of the hemodynamic data did not show any effect on the left-to-right shunt as a result of micro-

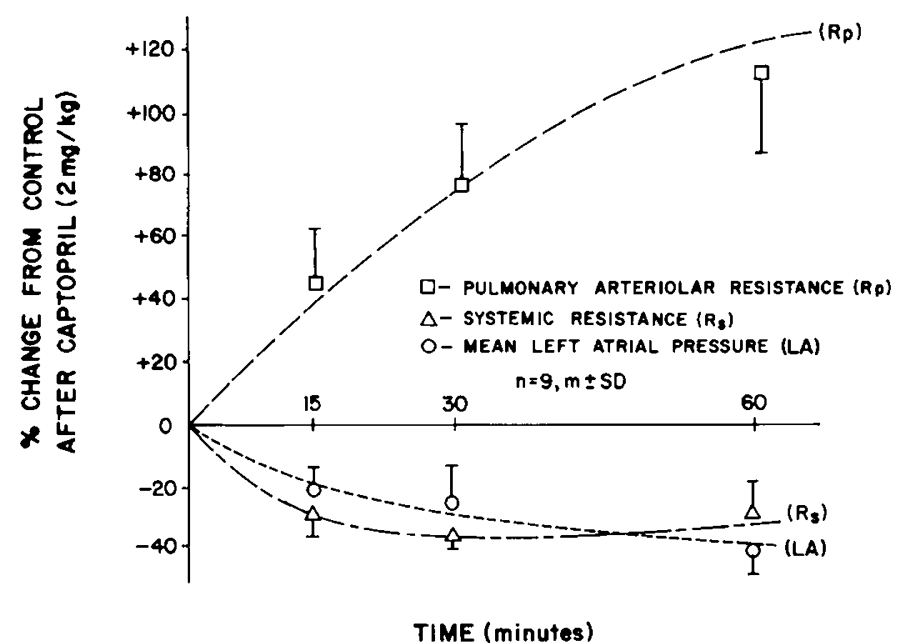

Fig. 2. Effect of captopril on systemic resistance $\left(R_{s}\right)$, pulmonary arteriolar resistance $\left(R_{p}\right)$, and mean left atrial pressure $(L A)$ as a function of time. The error bars indicate the SD and all points were significantly different from control. sphere infusion. After captopril administration, there was a fall in the systemic resistance and a rise in pulmonary resistance in these animals as also demonstrated in the dose response section. In addition, there was a fall in both left and right atrial pressures. The organ blood flow data are shown in Table 3. After captopril, there was no significant change in blood flow to any of the organs evaluated, although all of the flows tended to increase. Satisfactory mixing of the microspheres was demonstrated by right and left renal blood flow values within $5 \%$ of each other for each of the individual animals and within $2 \%$ of each other for the group. The right renal flow increased by $14 \%$ from $445 \pm 196$ to $505 \pm 257 \mathrm{ml} / 100 \mathrm{~g}$, but the change was not significant with this number of animals and the broad SD. The largest individual percent reduction in renal flow was $14 \%$ whereas the largest individual increase was $25 \%$. Similarly, the left ventricular blood flow increased from $228 \pm 45$ to $244 \pm 82 \mathrm{ml} / 100 \mathrm{~g}$, but again the change was insignificant. However, the ratio of left ventricular endocardial to epicardial blood flow was significantly increased from $1.17 \pm 0.27$ to $1.49 \pm 0.14(27 \%, p<0.05)$. The total right ventricular blood flow per gram of tissue tended to be less than the septal (data not shown) and left ventricular blood flow, but this difference was not significant.

\section{DISCUSSION}

The vasoconstricting action of the renin-angiotensin system promotes the pathologic cascade of increasing left-to-right shunt through a ventricular septal defect (4). The data presented in our report indicate that inhibition of converting enzyme activity with captopril favors the distribution of left ventricular output to the systemic circulation and reduces total pulmonary blood flow. The external minute work of the left ventricle is lowered and the left ventricular filling pressure is reduced despite the increase in systemic blood flow. The actions of captopril are mediated by a reduction in systemic resistance and a rise in pulmonary arteriolar resistance.

The effects of captopril on systemic resistance show saturation kinetics as demonstrated by the steep dose response curve with an $\mathrm{ED}_{50}$ of approximately $0.5 \mathrm{mg} / \mathrm{kg}$. Maximum effect of captopril occurred at $2 \mathrm{mg} / \mathrm{kg}$, and increasing the dose further to 10 $\mathrm{mg} / \mathrm{kg}$ produced no greater hemodynamic effect. There was no dose of captopril that significantly lowered the systemic blood flow or aortic pressure, possible detrimental effects, in this model.

Table 2. Pressures versus time after captopril ( $n=9$; mean \pm $S D)^{*+\dagger}$

\begin{tabular}{lcclc}
\hline & Control & \multicolumn{1}{c}{$15 \mathrm{Min}$} & \multicolumn{1}{c}{$30 \mathrm{Min}$} & \multicolumn{1}{c}{$60 \mathrm{Min}$} \\
\hline Ao $(\mathrm{mm} \mathrm{Hg})$ & $71.2 \pm 8.1$ & $63.0 \pm 9.7$ & $62.4 \pm 11.9$ & $67.4 \pm 9.1$ \\
PA (mm Hg) & $28.6 \pm 6.2$ & $28.3 \pm 6.4$ & $30.1 \pm 6.7$ & $31.3 \pm 8.8$ \\
LA (mm Hg) & $17.3 \pm 3.4$ & $13.5 \pm 3.4 \ddagger$ & $13.0 \pm 3.7 \ddagger$ & $10.8 \pm 2.8 \ddagger$ \\
HR (beats/min) & $148 \pm 25$ & $156 \pm 28$ & $153 \pm 25$ & $160 \pm 30$ \\
\hline
\end{tabular}

* Ao, PA, LA, mean aortic, pulmonary artery, and left atrial pressure, respectively.

$\dagger 2 \mathrm{mg} / \mathrm{kg}$.

$\ddagger \mathrm{p}<0.05$.

Table 1. Flow parameters and captopril dose (mean $\pm S D)^{*}$

\begin{tabular}{|c|c|c|c|c|c|c|c|c|c|}
\hline & \multicolumn{3}{|c|}{$0.05 \mathrm{mg} / \mathrm{kg}(n=5)$} & \multicolumn{3}{|c|}{$0.5 \mathrm{mg} / \mathrm{kg}(n=5)$} & \multicolumn{3}{|c|}{$5 \mathrm{mg} / \mathrm{kg}(n=6)$} \\
\hline & Control & $60 \mathrm{~min}$ & $\%$ change & Control & $60 \mathrm{~min}$ & $\%$ change & Control & $60 \mathrm{~min}$ & $\%$ change \\
\hline $\mathrm{Q}_{\mathrm{s}}$ liter $/ \mathrm{min} / \mathrm{M}^{2}$ & $2.24 \pm 0.45$ & $2.31 \pm 0.59$ & +3 & $2.15 \pm 0.5$ & $2.8 \pm 0.6$ & $+30 \dagger$ & $2.25 \pm 0.31$ & $2.8 \pm 0.46$ & $+24 \dagger$ \\
\hline $\mathrm{Q}_{\mathrm{p}}$ liter $/ \mathrm{min} / \mathrm{M}^{2}$ & $7.3 \pm 1.3$ & $7.3 \pm 1.4$ & 0 & $7.3 \pm 1.2$ & $6.7 \pm 1.2$ & -8 & $7.6 \pm 1.8$ & $6.3 \pm 1.2$ & -17 \\
\hline $\mathrm{Q}_{\mathrm{p}} / \mathrm{Q}_{\mathrm{s}}$ & $3.3 \pm 0.6$ & $3.2 \pm 0.6$ & -3 & $3.45 \pm 0.6$ & $2.52 \pm 0.8$ & $-27 \dagger$ & $3.4 \pm 0.5$ & $2.2 \pm 0.4$ & $-35 \dagger$ \\
\hline $\mathrm{Q}_{\mathrm{L}-\mathrm{R}}$ liter $/ \mathrm{min} / \mathrm{M}^{2}$ & $5.0 \pm 1.0$ & $5.0 \pm 1.1$ & 0 & $5.1 \pm 0.9$ & $3.9 \pm 1.2$ & $-24 \dagger$ & $5.4 \pm 1.6$ & $3.4 \pm 1.1$ & $-37 \dagger$ \\
\hline LVEMW liter $/ \mathrm{min} / \mathrm{M}^{2} / \mathrm{mm} \mathrm{Hg}$ & $546 \pm 110$ & $537 \pm 96$ & -2 & $558 \pm 108$ & $464 \pm 81$ & -17 & $531 \pm 124$ & $378 \pm 99$ & $-29 \dagger$ \\
\hline
\end{tabular}

${ }^{*} \mathrm{Q}_{\mathrm{s}}$, systemic flow; $\mathrm{Q}_{\mathrm{p}}$, pulmonary flow; $\mathrm{Q}_{\mathrm{LR}}$, left-to-right shunt flow across VSD; LVEMW, left ventricular external minute work.

$\dagger p<0.05$ 
Table 3. Organ blood flow* pre- and postcaptopril $(n=6$, mean $\pm S D) \dagger$

\begin{tabular}{lccc}
\hline & Control & Postcaptopril $\ddagger$ & \% change \\
\hline Right kidney & $445 \pm 196$ & $505 \pm 257$ & +14 \\
Left kidney & $438 \pm 198$ & $501 \pm 260$ & +14 \\
RV myocardium & $201 \pm 32$ & $224 \pm 69$ & +11 \\
LV myocardium & $228 \pm 45$ & $244 \pm 82$ & +7 \\
LV endo/epi & $1.17 \pm 0.27$ & $1.49 \pm 0.14$ & $+27 \S$ \\
Liver & $40.6 \pm 3.7$ & $44.8 \pm 4.0$ & +10 \\
Duodenum & $148 \pm 46$ & $164 \pm 82$ & +11 \\
Quadriceps & $7.7 \pm 1.3$ & $9.6 \pm 2.3$ & +25 \\
Systemic blood flow & $104 \pm 20$ & $133 \pm 27$ & $+28 \S$ \\
$\quad(\mathrm{ml} / \mathrm{kg} / \mathrm{min})$ & & &
\end{tabular}

* Expressed in $\mathrm{ml} / 100 \mathrm{~g}$ tissue $/ \mathrm{min}, n=6$.

$\dagger \mathrm{RV}$, right ventricular; $L V$, left ventricular.

$\ddagger$ Measured $45 \mathrm{~min}$ after intravenous captopril $(5 \mathrm{mg} / \mathrm{kg})$.

$\S p<0.05$.

It has been demonstrated that the immature animal appears to depend more on the renin-angiotensin system than the sympathetic system to maintain systemic resistance (10). The reninangiotensin system responds to the relative sodium-wasting state of the immature (11). The data from the VSD lamb show that inhibition of the renin-angiotensin effect on systemic resistance can be compensated for by other mechanisms. The reduction in systemic resistance after captopril resulted in only an insignificant drop in blood pressure at all doses inasmuch as there was a corresponding increase in systemic blood flow with each increment of reduction in systemic resistance.

The explanation for the rise in calculated pulmonary arterial resistance with captopril is uncertain. In normal individuals from several species including ovine, angiotensin II has a mild vasoconstricting effect on the pulmonary vasculature (12-14). Age and resting pulmonary vascular tone may affect response to angiotensin II $(14,15)$. Conversely, there is usually a mild pulmonary vasodilation with captopril (12). We have observed similar results in normal lambs. In lambs with VSD, angiotensin II infusion (pre- or postcaptopril) into the aorta has a pulmonary vasodilating effect, whereas infusion into the left atrium or pulmonary artery does not cause vasodilation (4). We infer from these data that the effects of angiotensin II (or captopril) on the pulmonary bed are indirect and possibly related to metabolism of angiotensin. We have observed in normal lambs (data not shown) that angiotensin III infusion into the pulmonary artery does indeed have a vasodilating effect. Captopril would prevent the conversion of either angiotensin I or II to angiotensin III. Pulmonary conversion to angiotensin II may be inhibited by the hyperoxic environment of the pulmonary vasculature with VSD (16), perhaps shifting angiotensin metabolism to the periphery. Certainly, other possible explanations (such as prostaglandin metabolism) exist to explain the response with VSD $(17,18)$. The marked fall in left atrial pressure may also contribute to the rise in pulmonary arteriolar resistance (19). In fact, the time dependence (Fig. 2) of the effects on the pulmonary resistance suggests that more than one mechanism may be operational. In any event, the transpulmonary pressure drop almost doubled after captopril in VSD lambs. The fact that the VSD was pressure restrictive would tend to isolate the pulmonary bed from changes in the systemic bed, making a passive response of the pulmonary bed to changes in systemic resistance unlikely.

Under basal conditions the systemic cardiac output in this study was low, although in a similar range to previously reported values for normal animals at 4-6 wk of age, and organ blood flow was normal (20). Using both the flow probe-measured cardiac output and the reference aortic sample permitted determination of organ flow despite the loss of microspheres to the pulmonary circulation through the VSD. There was excellent reproducibility as demonstrated by comparing right and left renal flows. Organ blood flow was preserved and tended to increase, although these changes were not statistically significant. Thus, the hypothesis that renin-angiotensin II stimulation may preserve renal blood flow and is important in maintaining other organ flow can be rejected. Inasmuch as angiotensin II effect promotes the left-to-right shunt and does not enhance organ blood flow (including renal), it appears that the response of the reninangiotensin system to a VSD is pathologic and that inhibition with captopril is physiologically beneficial.

The hemodynamic improvement with captopril would explain the change in microsphere-determined myocardial blood flow distribution. The endocardial-epicardial ratio increased significantly without a change in total myocardial flow. The redistribution of epicardial flow to the endocardium reflects the reduction in wall tension due to the lowered afterload and preload (left atrial pressure) (21). Inasmuch as myocardial external minute work was also reduced, captopril may favorably alter myocardial oxygen balance and reserve.

The stimulation in the renin-angiotensin system may be due to congestive heart failure and a relatively decreased cardiac output (5), catecholamine stimulation (22), or possibly the elevation in right atrial pressure and secondary increase in renal venous pressure (23). Increased atrial pressure may also cause release of ANF (24). Human studies have shown an increase in ANF with congestive failure due to VSD which may be related to elevated atrial pressures (5). ANF is known to antagonize many of the renin-angiotensin effects $(23,26)$; however, it does not seem to directly cause renin release and may, in fact, suppress renin secretion (27). Data on ANF in lambs with congestive failure are not presently available. The data presented here indicate that there is significant converting enzyme-dependent vasoconstriction despite the possible elevation of ANF. The rapid reduction in systemic resistance with captopril precedes changes in atrial pressure; thus it would be unlikely that captopril effect is mediated by change in ANF release. Captopril will also influence bradykinin metabolism, and some of the effects of captopril may be due to actions other than changes in angiotensin II production (28). However, we have previously shown that angiotensin II infusion completely reverses the effects of captopril (4).

Two areas of caution would be appropriate when trying to extrapolate these data. First, the animals for this project were allowed to maintain fluid balance without the influence of diuretic agents. In the situation of relative hypovolemia due to aggressive pharmacologic diuresis, it is possible that captopril may decrease preload, cardiac output, and thus organ blood flow (5). Second, although it appears that there is a selective effect on the systemic resistance as compared to the pulmonary resistance with captopril, these data were obtained in lambs with a VSD that imposes some inherent resistance due to its size (i.e. restrictive). With a larger, unrestricted ventricular septal defect it may be that the reduction in systemic resistance could not fully be compensated for by increases in systemic flow and reduction in pulmonary flow, and thus systemic arterial pressure and organ perfusion may be reduced.

The hemodynamic data presented here are similar to the beneficial effects reported for captopril with congestive failure due to poor myocardial function in the mature (29). These data extend the potential application of converting enzyme inhibitors to structural cardiac defects with congestive failure in the immature individual inasmuch as renin-angiotensin stimulation contributes to the pathologic cascade.

Acknowledgments. The authors wish to thank Alex Kralios, M.D. and Paul Christensen, M.D. for their assistance in performing the microsphere studies. We also thank Kris Sjoblom for manuscript editing and preparation. 


\section{REFERENCES}

1. Curtiss C, Cohn JN, Vrobel T, Franciosa JA 1978 Role of the renin-angiotensin system in the systemic vasoconstriction of chronic congestive heart failure. Circulation 58:763-770

2. Baylen BG, Johnson G, Tsang R, Srivastava L, Kaplan S 1980 The occurrence of hyperaldosteronism in infants with congestive failure. Am J Cardio 45:305-310

3. Williams GM, Davis JO, Freeman RH, DeForrest JM, Seymour AA, Rowe BP 1979 Effects of the oral converting enzyme inhibitor SQ14225 in experimental high output failure. Am J Physiol 236:F541-F545

4. Boucek MM, Chang R, Synhorst DP 1987 Renin-angiotensin II response to the hemodynamic pathology with ventricular septal defect. Circ Res (in press)

5. Packer M 1987 Why do the kidneys release renin in patients with congestive heart failure? A nephrocentric view of converting-enzyme inhibition. Am J Cardiol 60:179-184

6. Rudolph AM 1965 The effects of postnatal circulatory adjustments in congenital heart disease. Pediatrics 36:763-772

7. Boucek MM, Chang R, Synhorst DP 1984 Vasodilators and ventricular septa defect: Comparison of prazosin, minoxidil, and hydralazine in a chronic lamb model. Pediatr Res 18:859-864

8. Heymann MA, Payne BD, Hoffman JIE, Rudolph AM 1977 Blood flow measurements with radionuclide-labeled microspheres. Prog Cardiovasc Dis 20:55-79

9. Hansen NB, Nowicki PT, Miller RR, Malone T, Bickers RG, Menke JA 1986 Alterations in cerebral blood flow and oxygen consumption during prolonged hypocarbia. Pediatr Res 20:147-150

10. Tabsh K, Nuwayhid B, Murad E, Ushioda R, Erkkola R, Brinkman CR, Assali NS 1982 Circulatory effects of chemical sympathectomy in fetal, neonatal, and adult sheep. Am J Physiol. 243:H113-H122

11. Siegel SR 1983 The effects of salt loading on the renin-angiotensin control of blood pressure in the newborn lamb. Pediatr Res 17:210-212

12. Goll HM, Nyhan DP, Geller HS, Murray PA 1986 Pulmonary vascular responses to angiotensin II and captopril in conscious dogs. J Appl Physiol 61:1552-1559

13. Suggett AJ, Mohammed FH, Barer GR 1980 Angiotensin, hypoxia, verapamil and pulmonary vessels. Clin Exp Pharmacol Physiol 7:263-274

14. Hansen TN, LeBlanc AL, Gest AL 1985 Hypoxia and angiotensin II infusion redistribute lung blood flow in lambs. J Appl Physiol 58;812-818

15. Gillespie MN, Olson JW, Reinsel CN, O'Connor WN, Altiere RJ 1986 Vascular hyperresponsiveness in perfused lungs from monocrotaline-treated rats. Am J Physiol 251:109-114

16. Oparil S, Daise M, Abrahams C, Winternitz SR, Szidon JP 1987 Hyperoxia induced converting enzyme insufficiency in conscious rat: cardiovascular effects. Exp Lung Res 12:37-56

17. Blumberg AL, Denny SE, Marshall GR, Needleman P 1977 Blood vesselhormone interactions: angiotensin, bradykinin and prostaglandins. Am J Physiol 232:H305-H310

18. Kadowitz PJ, McNamara DB, She HS, Spannhake EN, Hyman AL 1982 Prostaglandin response in the pulmonary vascular bed. In: Peckham GJ, Heyman MA (eds) Cardiovascular Sequelae of Asphyxia in the Newborn. Report of the Eighty-Third Ross Conference on the Pediatric Research, pp 84-92

19. Rudolph AM, Auld PAM 1960 Physical factors affecting normal and serotonin constricted pulmonary vessels. Am J Physiol 198:864-872

20. Klopfenstein HS, Rudolph AM 1978 Postnatal changes in the circulation and responses to volume loading in sheep. Circ Res 42:839-845

21. Hoffman JIE 1978 Determinants and prediction of transmural myocardial perfusion. Circulation 58:381-391

22. Lumbers ER, Lewes JL 1979 The actions of vasoactive drugs on fetal and maternal plasma renin activity. Biol Neonate 35:23-32

23. Kastner PR, Hall JE, Guyton AC 1982 Renal hemodynamic responses to increased renal venous pressure: Role of angiotensin II. Am J Physiol 243:F260-F264

24. Laragh JH 1985 Atrial natriuretic hormone, the renin-aldosterone axis, and blood pressure-electrolyte homeostasis. N Engl J Med 313:1330-1340

25. Matsuoka S, Kuranashi Y, Tomimatsu H, Miyao M, Yamazaki Y, Nishiuchi T, Saito S 1987 Plasma atrial natriuretic peptide levels in patients with ventricular septal defect. J Pediatr 110:578-580

26. Proctor KG, Bealer SL 1987 Selective antagonism of hormone-induced vasoconstriction by synthetic atrial natriuretic factor in the rat microcirculation. Circ Res 61:42-49

27. Maack $\Upsilon$, Marion DN, Camargo MJF, Kleinert HD, Laragh JH, Vaughan ED, Atlas SA 1984 Effects of auriculin (atrial natriuretic factor) on blood pressure, renal function, and the renin-aldosterone system in dogs. Am $J$ Med 77:1069-1075

28. William GH, Hollenberg NK 1977 Accentuated vascular and endocrine response to SQ20881 in hypertension. N Engl J Med 297:184-188

29. Faxon DP, Creager MA, Halperin JL, Gauras H, Coffman JD, Ryan TJ 1980 Central and peripheral hemodynamic effects of angiotensin inhibition in patients with refractory congestive heart failure. Circulation 61:925-930 